University of Nebraska - Lincoln

DigitalCommons@University of Nebraska - Lincoln

Faculty Publications in Food Science and Technology

Food Science and Technology Department

$3-2012$

\title{
Hybrid and environment effects on popcorn kernel physiochemical properties and their relationship to microwave popping performance
}

\author{
Jess C. Sweley \\ University of Nebraska-Lincoln \\ Devin J. Rose \\ University of Nebraska-Lincoln, drose3@unl.edu \\ David S. Jackson \\ University of Nebraska-Lincoln, djackson1@unl.edu
}

Follow this and additional works at: https://digitalcommons.unl.edu/foodsciefacpub

Part of the Food Science Commons

Sweley, Jess C.; Rose, Devin J.; and Jackson, David S., "Hybrid and environment effects on popcorn kernel physiochemical properties and their relationship to microwave popping performance" (2012). Faculty Publications in Food Science and Technology. 115.

https://digitalcommons.unl.edu/foodsciefacpub/115

This Article is brought to you for free and open access by the Food Science and Technology Department at DigitalCommons@University of Nebraska - Lincoln. It has been accepted for inclusion in Faculty Publications in Food Science and Technology by an authorized administrator of DigitalCommons@University of Nebraska - Lincoln. 


\title{
Hybrid and environment effects on popcorn kernel physiochemical properties and their relationship to microwave popping performance
}

\author{
Jess C. Sweley, ${ }^{1}$ Devin J. Rose, ${ }^{1}$ and David S. Jackson ${ }^{1,2}$ \\ 1. Department of Food Science and Technology, University of Nebraska-Lincoln, 143 Filley Hall, Lincoln, NE 68583, USA \\ 2. Agriculture Research Division, University of Nebraska-Lincoln, 207 Agriculture Hall, Lincoln, NE 68583, USA \\ Corresponding author - D. J. Rose, emaildrose3@unl.edu
}

\begin{abstract}
The objective of this study was to characterize the effect of hybrid and environment on physical and chemical characteristics of popcorn kernels that have shown importance in predicting end-use quality. Three popcorn hybrids grown in three different environments were tested for physiochemical attributes and popping performance. Hybrid had a significant effect on kernel sphericity, time-to-grind, dietary fiber, sugars, and starch. Environment effect alone affected total mineral content. Hybrid and environment main effects influenced test weight, tangential abrasive dehulling device index, thousand-kernel weight, total carbohydrates, and kernel protein content. Oil adherence to the bag averaged $15.8 \%$ and was proportional to oil amount added prior to microwave popping. Unpopped kernels averaged $11.4 \pm 5 \cdot 3 \%$. Most unpopped kernels were observed to successfully pop when heated a second time in microwave tests. Expansion volume was $44.7 \pm 3.7$ and $47.3 \pm 6.4 \mathrm{~cm}^{3} / \mathrm{g}$, depending on the method of determination. Expansion volume was correlated $(p<0.05)$ with several kernel physiochemical parameters that were influenced by hybrid effect. Sphericity, thousand-weight, and total fat are physiochemical characteristics that appear to be good predictors $(p<0.05)$ of expansion volume.
\end{abstract}

Keywords: Zea mays, Popcorn, Expansion volume, Unpopped kernels

\section{Introduction}

The most studied and reported quality factors for popcorn (Zea mays var everta) have been expansion volume and the number of unpopped kernels (Ziegler, 2001). High pop expansion volume is correlated with desirable consumer attributes including improved texture and consumer acceptability (Ceylan and Karababa, 2001; Dofing et al., 1990), while unpopped kernels are an undesirable nuisance to consumers and unrealized profit for producers.

Popcorn expansion volume has been shown to be a quantitative trait with high heritability and influenced by three to five major genes (Lu et al., 2003; Ziegler, 2001). Breeding methods used to improve dent corn are commonly used for popcorn, with the primary distinction being that the trait of emphasis in popcorn has historically been popping performance whereas dent corn breeders have usually focused on grain yield (Ziegler, 2001). While expansion volume tends to be negatively correlated with grain yield, breeding methods which use additive genetic variation for expansion volume and dominance variation for grain yield will likely result in simultaneous improvement in both producer yield and end-use quality traits (Dofing et al., 1990).
Correlating intrinsic kernel characteristics with final performance quality measures can provide simple and reliable prediction methods to breeders and producers (Dorsey-Redding et al., 1991). As such, several studies have investigated and elucidated popcorn kernel characteristics that influence expansion volume. Some of the phenotypic characteristics shown to affect pop volume include physical traits such as kernel size, shape, density, hardness, and pericarp thickness, as well as composition attributes such as levels of zein protein and the types of fatty acid in the kernel (Borras et al., 2006).

Evaluating genetic and environmental mechanisms which influence phenotypic characteristics and predict performance is an essential part of plant breeding (Stuber et al., 1992). The physical and biochemical characteristics of popcorn kernels are known to vary depending on the genetics, growing environment, and agronomic practices used (Ziegler, 2001). While end-quality popping performance has been the primary focus of growers and popcorn breeding programs (Dofing et al., 1991), the effect of hybrid and environment on physical and biochemical properties of popcorn kernels and the relationship among these properties has not been comprehensively studied. The objectives of this investigation were to determine the effects of hybrid and growing envi- 
ronment on the physical properties and biochemical composition of popcorn kernels and establish the relationships among intrinsic kernel quality characteristics, as well as to relate kernel properties to end-use microwave popping performance.

\section{Experimental}

\subsection{Popcorn samples}

Three commercial, butterfly-type popcorn hybrids, YPK-213, YPK-313, and YPK-321, were supplied by ConAgra Foods, Inc. (Omaha, NE USA). Hybrids were planted and grown in strip plots in Nebraska, Indiana, and Ohio, three states in the Midwestern USA, during 2009. These three states annually produce over $250,000 \mathrm{~kg}$ of popcorn, which represents $65 \%$ of the commercial popcorn grown in the USA (National Agricultural Statistics Service, 2007). The Nebraska strip plot was irrigated land, while Indiana and Ohio strip plots were non-irrigated. Fertilization, weed, and pest control were applied according to standard agronomic practices at each location. All hybrids were harvested and thrashed by combine at commercial maturity when their field moisture contents were less than $18 \%$. Samples (a total of three from each plot) were cleaned, bulked packed, and tempered to $14 \%$ moisture by storing at $21.5{ }^{\circ} \mathrm{C}$ and $73 \%$ rh until used for experimentation, which occurred from May 2010 to January 2011.

\subsection{Composition and physical property testing}

Compositional and physical property analyses were performed on conditioned popcorn samples after equilibrating for a minimum of $120 \mathrm{~d}$ at storage conditions and attainment of desired moisture content of $14.0 \pm 0.5 \%$ as measured using a Dickey-john GAC III moisture analyzer. More accurate kernel moisture contents were determined using the method described below. Kernel moisture content of $14.0 \%$ was selected for the target moisture content as it has been reported to be the optimum level for microwave popping performance (Gökmen, 2004; Ziegler, 2001). Thousand-kernel weight (g) was measured by randomly selecting and weighing 1000 intact kernels. Test weight $(\mathrm{kg} / \mathrm{hl})$ was measured using the United States Department of Agriculture (USDA, 1990) Federal Grain Inspection Service Method. True kernel density $\left(\mathrm{g} / \mathrm{cm}^{3}\right)$ was determined using an air-comparison pycnometer (Pomeranz et al., 1984; Quantachrom pycnometer Boynton Beach, FL) equipped with ultrapure nitrogen as displacement gas. Tangential abrasive dehulling device (TADD) index was determined by calculating the percentage of kernel weight remaining after abrading $40 \mathrm{~g}$ of sample for 10 min using a TADD instrument (Venables Machine Works LTD, Saskatoon, Saskatchewan, Canada) with no. 36 grit disk under constant vacuum aspiration (Reichert et al., 1986). Stenvert kernel hardness was determined by measuring time required to grind $20 \mathrm{~g}$ of intact popcorn kernels and the ground sample height $(\mathrm{mm})$ using a Kinematica AG Polymix Grinder (Model PX-MFC 9o D, Lucerne, Switzerland) with a $2 \mathrm{~mm}$ screen and operated at $3600 \mathrm{rpm}$ measured using the integrated tachometer (Pomeranz et al., 1985). Average kernel sphericity was calculated as the ratio of geometric mean diameter (cubic root of the multiplied length, width, and thickness) and kernel length for 30 randomly-selected kernels per sample, as measured with a digital micrometer (Mitutoya America Corp., Aurora, IL). Five observations were made for each experimental unit for thousand-kernel weight, pycnometer density, and Stenvert hardness tests. Six observations were taken per sample for TADD index, seven sample reps were observed for test weight, and thirty observations per sample were made for sphericity.
Compositional characteristics were measured for the popcorn kernels after using a two-step milling process of chopping for $20 \mathrm{~s}$ in a Blixer 3 blender (Robot Coupe, USA) and then grinding with a Kitchen Mill Model 91 (Blentech, USA). Analyses of total fat, saturated fat, fatty acids, fiber, sugar, moisture, and minerals were determined using standard methods (996.06, 950.46, 992.15, and 984.27, respectively; AOAC, 2010), while protein, total carbohydrates, sugars, and starch were determined using the preparation and method modifications for popcorn as described previously (Sweley et al., 2011). Amylose and amylopectin were measured using the modified dual-wavelength iodine binding procedure described by Zhu et al. (2008). For all compositional analysis, three replications were made per sample, and all reported data were adjusted to $14.0 \%$ moisture basis (Dorsey-Redding et al., 1990).

\subsection{Pop performance testing}

A randomized, D-optimal design requiring a total of 65 runs was developed using Design Expert statistical software (version 8.o, Stat-Ease, Inc., Minneapolis, MN) in order to assess popping performance across a range of prevalent microwave wattages and different amounts of oil added to the kernels. The nine hybrid $\times$ environment popcorn samples previously described were used as the kernels for experiments. Popcorn kernels and oil were weighed into pre-folded, commercially standard, bi-layer microwavable paper bags $(14.92 \mathrm{~cm} \times 29.53 \mathrm{~cm})$ containing an aluminum-coated polyester susceptor $(13.65 \mathrm{~cm} \times 16.51 \mathrm{~cm})$ embedded at the bottom center of the bag gusset. The total weight of kernels and oil was fixed at $77 \mathrm{~g}$, which was established after conducting pretesting to verify that popping would not be constricted by the bag. The corn-oil ratios used in this study (2:1-16:1) were selected to encompass the prevalent range of oil levels (6-30\%) found in microwave popcorn products being sold in the US market (U.S. Department of Agriculture, 2010). The oil used for all testing was a commercially-available blend of palm oil and palm oil stearin (Archer Daniels Midland Company product 84560o, Decatur, IL).

Popping tests were completed using the following three microwave ovens with distinct power outputs, internal cavity dimensions, and manufacturers: (a) Panasonic model NN-H765BF (1250 W, $0.45 \mathrm{~m}^{3}$ internal cavity), (b) General Electric model JEn6oWC (1100 W, $0.31 \mathrm{~m}^{3}$ internal cavity), and (c) Samsung MW83oWA (80o W, o.17 $\mathrm{m}^{3}$ internal cavity). The actual power output for the three microwaves was 1240,1050 , and $750 \mathrm{~W}$, respectively, which was determined by taking $70 \%$ of the measured temperature change of $1000 \mathrm{~g}$ of deionized water $\left(20{ }^{\circ} \mathrm{C}\right)$ after heating for $62 \mathrm{~s}$ on high power (Schiffmann, 1987).

For each experimental run, microwave popping tests were performed immediately after bag preparation by placing unfolded bags in the center of the microwave with susceptor-side down and popping on high power until the interval between pops slowed to $2 \mathrm{~s}$. After popping, bag contents were poured into a steel sieve with round-hole, $7.94 \mathrm{~mm}$ openings (Seedburo, USA Model oo70) to remove unpopped kernels. The empty paper bag and any residual oil was weighed, and used to calculate the percentage (by weight) of original oil lost to the bag during popping. Popped popcorn flakes were weighed and then poured into a 4 L graduated cylinder, which was inverted once and the resultant pop volume rounded to the nearest $25 \mathrm{~mL}$ graduation.

The conventional manner of reporting microwave popcorn expansion volume has been the volume of popped corn per original weight of unpopped popcorn (Dofing et al., 1990; Mohamed et al., 1993). An alternative method for determining expansion volume has been reported by Pordesimo et al. (1990) as the ratio of pop volume per weight of popped kernels. Both methods of determining expansion volume were calculated and reported in this study. 
Table 1. Physical properties of three popcorn hybrids grown in three different environments.

\begin{tabular}{|c|c|c|c|c|c|c|}
\hline & \multicolumn{3}{|c|}{ Hybrid } & \multicolumn{3}{|c|}{ Environment } \\
\hline & YPK-213 & YPK-313 & YPK-321 & Indiana & Nebraska & Ohio \\
\hline Thousand-Weight (g) & $159 \cdot 5 \pm 9.3 \mathrm{C}$ & $172.6 \pm 7.8 \mathrm{a}$ & $166.0 \pm 8.4 \mathrm{~b}$ & $175.6 \pm 5.7 \mathrm{a}$ & $156.3 \pm 6.9 c$ & $166.3 \pm 5.1 \mathrm{~b}$ \\
\hline Test Weight (kg/hl) & $87.0 \pm 1.9 \mathrm{~b}$ & $89.2 \pm 0.8 \mathrm{a}$ & $86.7 \pm 2.6 b$ & $85.8 \pm 2.6 b$ & $88.9 \pm 0.8 a$ & $88.3 \pm 1.2 b$ \\
\hline Pycnometer Density $\left(\mathrm{g} / \mathrm{cm}^{3}\right)$ & $1.38 \pm 0.01 \mathrm{a}$ & $1.38 \pm 0.01 \mathrm{a}$ & $1.38 \pm 0.01 \mathrm{a}$ & $1.38 \pm 0.01 \mathrm{a}$ & $1.38 \pm 0.01 \mathrm{a}$ & $1.38 \pm 0.01 \mathrm{a}$ \\
\hline Stenvert Time-to-Grind (s) & $14.6 \pm 0.6 \mathrm{a}$ & $13.8 \pm 0.7 \mathrm{~b}$ & $14.3 \pm 0.7 \mathrm{ab}$ & $14.4 \pm 0.7 \mathrm{a}$ & $13.9 \pm 0.8 b$ & $14.3 \pm 0.6 \mathrm{ab}$ \\
\hline Stenvert Height (cm) & $7.0 \pm 0.2 \mathrm{a}$ & $7.0 \pm 0.1 \mathrm{a}$ & $7.0 \pm 0.1 \mathrm{a}$ & $7.0 \pm 0.1 \mathrm{a}$ & $7.0 \pm 0.1 \mathrm{a}$ & $7.0 \pm 0.1 \mathrm{a}$ \\
\hline TADD index & $40.9 \pm 2.5 c$ & $45.8 \pm 2.7 a$ & $43.8 \pm 2.8 b$ & $40.5 \pm 2.1 \mathrm{C}$ & $46.5 \pm 2.3 a$ & $43.5 \pm 2.3 b$ \\
\hline Sphericity (\%) & $74.6 \pm 0.0 \mathrm{a}$ & $71.9 \pm 0.0 \mathrm{~b}$ & $72.4 \pm 0.1 \mathrm{~b}$ & $72.9 \pm 0.1 \mathrm{a}$ & $73.2 \pm 0.1 \mathrm{a}$ & $72.8 \pm 0.1 \mathrm{a}$ \\
\hline
\end{tabular}

Mean values \pm SD in same row followed by the same letter within each factor (hybrid or environment $)$ are not significantly different $(P<0.05) . n=3$.

In order to further examine the potential pop viability of kernels which did not pop, unpopped kernels from each hybrid $\times$ environment sample were collected and combined. Using the same paper bags described previously, $28 \mathrm{~g}$ unpopped kernels were weighed without any additional oil and popped using the $1250 \mathrm{~W}$ Panasonic microwave. The resultant number of unpopped kernels was counted, weighed, and converted to a percentage of the preceding $28 \mathrm{~g}$ starting weight. The limited amount of unpopped kernels collected during initial experiments constrained the starting kernel weight and permitted only a single sample replicate per treatment combination for re-pop testing, although two-way ANOVA analysis could still be used for mean comparisons between hybrids and environment effects $(n=3)$.

\subsection{Statistical analysis}

All statistical analyses were performed using SAS software (version 9.2, SAS Institute, Cary, NC). Kernel physical and compositional properties and pop performance comparisons used two-way analysis of variance (ANOVA) with fixed effects for hybrid and environment to make comparisons using Fisher's least significant differences (LSD) test at $\alpha=0.05$. Only main effects of hybrid and environment were included ANOVA calculations since the experimental design did not include field plot replication. The relationship of kernel hybrid and environment to kernel physiochemical parameters, as well as the relationship between physiochemical parameters and popping performance measures, was analyzed using the SAS correlation (CORR) procedure.

\section{Results and discussion}

\subsection{Kernel physicochemical parameters}

Significant differences in physical and compositional properties between the popcorn kernels were observed (Table 1). Test weight varied significantly among the samples $(p<0.05)$, which might be due to its being a measure of bulk density and therefore dependent on many factors beyond the kernel density including kernel size and shape, packing, and void volume, among others (Lee et al., 2007). While thousand-kernel weight eliminates the variability in measurement caused by packing and void volume, the results of this study showed thousand-kernel weight measures to be more variable than test weight. In contrast, pycnometer density was shown to have the highest reproducibility among all physical properties tested, which is consistent with results reported for conventional maize (Lee et al., 2007). Because pycnometer density provides an indirect indication of the percent of hard and soft endosperm found in the kernel (Lee et al., 2007), it may be especially relevant for popcorn since it has been proposed that popcorn kernels with larger amounts of hard endosperm will have greater expansion ratio (Hoseney et al., 1983).

The values for thousand-kernel weight, test weight, pycnometer density, and kernel sphericity were consistent with the range of values reported previously for popcorn kernels (Ceylan and Karababa, 2001; Mohamed et al., 1993; Pordesimo et al., 1990). Ertas et al. (2009) reported lower values for thousand-kernel weight and test weight than the results observed in this study, probably due to testing by Ertas et al. being conducted on kernels conditioned to below $8 \%$ moisture content versus the $14 \%$

Table 2. Biochemical composition of three popcorn hybrids grown in three different environments.

\begin{tabular}{|c|c|c|c|c|c|c|}
\hline & \multicolumn{3}{|c|}{ Hybrid } & \multicolumn{3}{|c|}{ Environment } \\
\hline & YPK-213 & YPK-313 & YPK-321 & Indiana & Nebraska & Ohio \\
\hline Total Fat (\%) & $2.8 \pm 0.2 \mathrm{a}$ & $2.9 \pm 0.2 \mathrm{a}$ & $3.0 \pm 0.3 a$ & $3.0 \pm 0.2 \mathrm{a}$ & $2.9 \pm 0.2 \mathrm{a}$ & $3.0 \pm 0.2 \mathrm{a}$ \\
\hline Total Carbohydrate (\%) & $72.3 \pm 0.4 \mathrm{C}$ & $73.9 \pm 0.8 \mathrm{a}$ & $73.1 \pm 0.7 b$ & $72.7 \pm 0.6 b$ & $73.7 \pm 1.3 a$ & $72.9 \pm 0.6 b$ \\
\hline Starch (\%) & $61.5 \pm 2.7 b$ & $63.4 \pm 3.8 \mathrm{ab}$ & $65.3 \pm 1.8 \mathrm{a}$ & $63.5 \pm 3.0 \mathrm{a}$ & $63.6 \pm 3.9 a$ & $63.1 \pm 2.9 a$ \\
\hline Amylose (\%) & $9.1 \pm 0.5 b$ & $9.6 \pm 0.8 \mathrm{ab}$ & $9.8 \pm 1.0 \mathrm{a}$ & $9.5 \pm 0.5 \mathrm{ab}$ & $10.1 \pm 0.8 \mathrm{a}$ & $9.0 \pm 0.8 b$ \\
\hline Amylopectin (\%) & $52.3 \pm 2.7 b$ & $53.8 \pm 3.5 \mathrm{ab}$ & $55 \cdot 5 \pm 2.2 \mathrm{a}$ & $55.0 \pm 2.7 a$ & $53.5 \pm 3.6 a$ & $54.1 \pm 3.1 \mathrm{a}$ \\
\hline Dietary Fiber (\%) & $11.1 \pm 0.6 \mathrm{a}$ & $11.4 \pm 0.3 \mathrm{a}$ & $10.1 \pm 0.3 b$ & $11.0 \pm 0.6 \mathrm{a}$ & $11.0 \pm 0.8 \mathrm{a}$ & $10.7 \pm 0.8 \mathrm{a}$ \\
\hline Sugars (\%) & $0.46 \pm 0.02 \mathrm{c}$ & $0.65 \pm 0.08 \mathrm{a}$ & $0.51 \pm 0.04 b$ & $0.56 \pm 0.11 \mathrm{a}$ & $0.56 \pm 0.11 a$ & $0.50 \pm 0.07 b$ \\
\hline Protein (\%) & $9.9 \pm 0.2 \mathrm{a}$ & $8.1 \pm 0.8 c$ & $8.8 \pm 0.6 b$ & $9.2 \pm 0.6 \mathrm{a}$ & $8.4 \pm 1.3 b$ & $9.2 \pm 0.5 \mathrm{a}$ \\
\hline Total Minerals (\%) & $1.0 \pm 0.1 \mathrm{a}$ & $1.0 \pm 0.1 \mathrm{a}$ & $1.1 \pm 0.1 \mathrm{a}$ & $1.1 \pm 0.0 \mathrm{a}$ & $1.1 \pm 0.1 \mathrm{a}$ & $0.9 \pm 0.1 b$ \\
\hline \multicolumn{7}{|l|}{ Fatty acid composition* } \\
\hline Palmitic Acid (\%) & $16.4 \pm 0.4 \mathrm{a}$ & $15.0 \pm 0.2 \mathrm{C}$ & $15.8 \pm 0.4 b$ & $15.8 \pm 0.8 \mathrm{a}$ & $15.9 \pm 0.7 \mathrm{a}$ & $15.7 \pm 0.5 \mathrm{a}$ \\
\hline Stearic Acid (\%) & $1.9 \pm 0.1 \mathrm{~b}$ & $1.7 \pm 0.1 \mathrm{C}$ & $2.1 \pm 0.1 \mathrm{a}$ & $1.9 \pm 0.2 \mathrm{a}$ & $1.8 \pm 0.1 \mathrm{~b}$ & $2.0 \pm 0.2 \mathrm{a}$ \\
\hline Oleic Acid (\%) & $20.8 \pm 0.8 b$ & $22.0 \pm 0.7 \mathrm{a}$ & $21.7 \pm 0.7 \mathrm{a}$ & $21.3 \pm 0.7 b$ & $21.1 \pm 0.7 b$ & $22.2 \pm 0.8 \mathrm{a}$ \\
\hline Linoleic Acid (\%) & $58.3 \pm 0.3 a$ & $58.5 \pm 0.8 \mathrm{a}$ & $57.7 \pm 0.5 b$ & $58.4 \pm 0.7 a$ & $58.5 \pm 0.5 \mathrm{a}$ & $57.6 \pm 0.4 \mathrm{~b}$ \\
\hline Linolenic Acid (\%) & $1.4 \pm 0.1 \mathrm{a}$ & $1.3 \pm 0.0 \mathrm{~b}$ & $1.3 \pm 0.1 \mathrm{ab}$ & $1.3 \pm 0.1 \mathrm{a}$ & $1.4 \pm 0.1 \mathrm{a}$ & $1.3 \pm 0.1 \mathrm{a}$ \\
\hline All Other (\%) & $1.2 \pm 0.4 \mathrm{a}$ & $1.5 \pm 0.3 a$ & $1.4 \pm 0.4 \mathrm{a}$ & $1.3 \pm 0.4 \mathrm{a}$ & $1.4 \pm 0.3 a$ & $1.3 \pm 0.3 a$ \\
\hline
\end{tabular}

Mean values \pm SD in same row followed by the same letter within each factor (hybrid or environment) are not significantly different $(P<0.05)$. All values reported on $14.0 \%$ moisture content $(w b) . n=3$.

* Fatty acids reported as percentage of total fat in kernel. $n=3$. 
moisture content used in this study and recommended for optimum pop performance. Values for kernel sphericity were also consistent with the range of values previously reported previously for popcorn kernels (Ceylan and Karababa, 2001; Ertas et al., 2009; Mohamed et al., 1993; Pordesimo et al., 1990).

TADD index has not been commonly reported for popcorn, but it showed relatively low variability in test measurements and provided delineation between different hybrids and growing environments. In addition, the post-abrasion samples revealed a remarkably vibrant yellow appearance in the kernel endosperm that was not observed with grinding or fracturing kernels. The range of TADD index values observed for experimental units in this study was $38.2-49.1 \%$ with an average of $43.5 \pm 3.4 \%$, which is greater than the range of mean TADD indices (27.8-31.9\%) reported for four clusters of diverse conventional maize hybrids (Lee et al., 2007). This is to be expected since the TADD index measures hardness by abrading the outer kernel layers, and the cell wall matrix found in popcorn pericarp has greater structural organization than conventional corn, which is a distinguishing feature that enables pop mechanics (Hoseney et al., 1983; Tandjung et al., 2005). Thus, it may be that TADD index provides a rapid, indirect measure of the relative pericarp organization for popcorn.

The compositional analysis also revealed significant differences among the popcorn samples (Table 2). The ranges of protein content and starch observed for individual popcorn kernel samples in this study were similar to those reported previously for popcorn by Park et al. (200o). Amylose and amylopectin concentrations were lower than previously reported for popcorn kernels (Borras et al., 2006; Park et al., 2000), which may simply be attributed to sample variation between the studies, or it may be due to differences in analytical methodologies.

Across all hybrid and environment treatments, the fatty acid composition of popcorn kernel lipids consisted primarily of linoleic, oleic, and palmitic acids, while stearic, linolenic, and all other fatty acids were less than $\mathbf{2} \%$ (Table 2 ). The preponderance of fatty acids is similar to values reported previously (Borras et al., 2006; Park et al., 2000).

Several notable relationships were observed from analysis of the correlation coefficients among the popcorn kernel physical and chemical properties (Table 3 ). Protein had a significant inverse correlation with both sugars and total carbohydrates. Total carbohydrates were positively correlated with TADD index but negatively correlated with time-to-grind, while protein was negatively correlated with TADD index and positively correlated with time-to-grind. The positive correlation between protein and time-to-grind is consistent with previous studies in maize (Dorsey-Redding et al., 1991; Shandera et al., 1997). Starch was positively correlated with amylopectin and negatively correlated with dietary fiber, but no relationships between starch and physical measures were observed. While total fat was predictably correlated with several fatty acids, total fat was not related to any other physical or chemical measure, whereas relationships between oil and starch and oil and kernel density have been reported for conventional maize (Dorsey-Redding et al., 1991). Kernel sphericity had a significant inverse correlation with sugars and oleic acid, while test weight and thousand-weight were not correlated with compositional measures.

\subsection{Hybrid and environment influence on kernel properties}

Hybrid and/or growing location had a significant effect on most physiochemical parameters for popcorn kernels measured in this study, except percent total fat, pycnometer density, and Stenvert column height. Both hybrid and environment main effects had a significant $(p<0.01)$ effect on physical kernels tests of

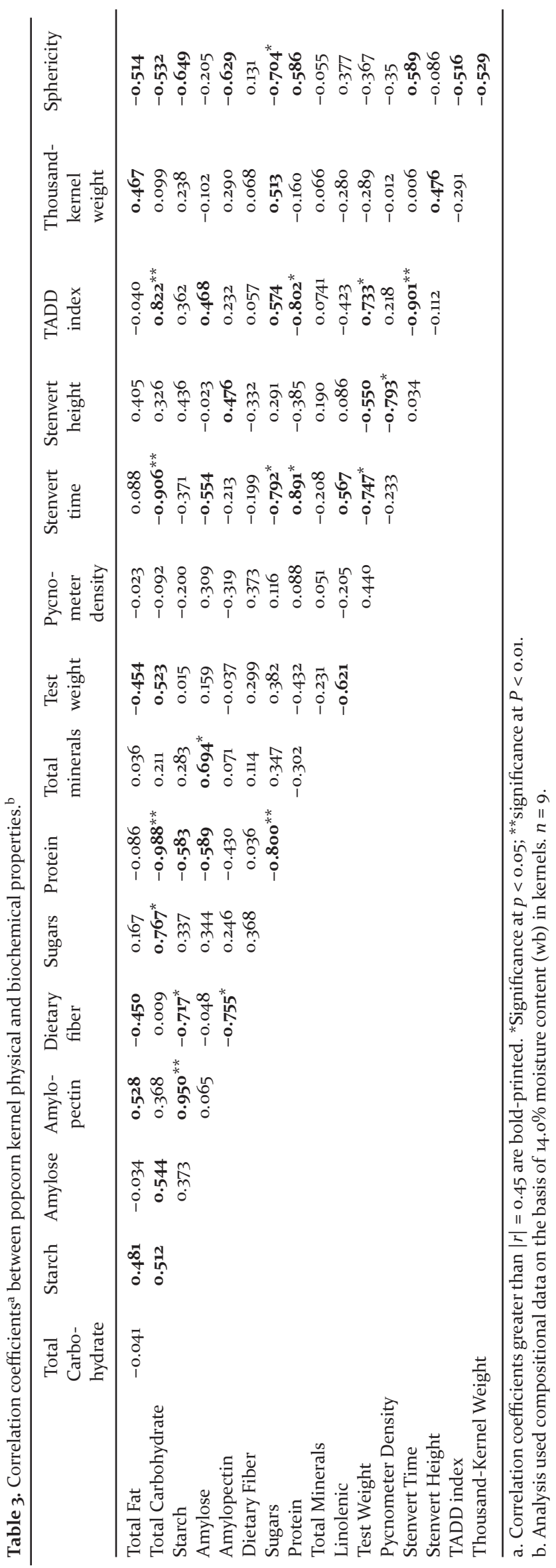


thousand-kernel weight, test weight, TADD index, as well as the levels of total carbohydrates and protein. Hybrid main effect alone was shown to influence sphericity, time-to-grind, dietary fiber, sugars, and total starch. These results are generally consistent with previous studies on popcorn showing that hybrid has a significant effect on some select kernel physical and/or compositional characteristics (Ceylan and Karababa, 2001; Park et al., 2000; Soylu and Tekkanat, 2007), although Park et al. (2000) also found hybrid to have an effect on total fat, and no significant effects were observed in kernel fat in this study, perhaps due to the specific hybrids used.

Environment was shown to be the only effect showing significance for total minerals. Further analysis in this study specifically uncovered that iron, phosphorus, and potassium contents of popcorn kernels were significantly affected by environment. These results agree with previous findings in other cereal grains that levels of potassium, phosphorus, and iron vary as a result of environmental factors such as the use of irrigation versus rainfall, fertilizer content, and the nature of the soil itself (Greaves and Hirst, 1929).

The advancement in quantitative genetics and mapping of quantitative trait loci (QTL) for popcorn expansion volume might suggest that estimating the magnitude of variance for kernel physicochemical attributes is immaterial, but it is unlikely that a single genotype exists that will perform best in all environments, even when those environments are relatively similar (Allard and Bradshaw, 1964). To wit, investigation of genetic mechanisms for popcorn by Li et al. (2006) revealed that only 22.7\% of QTLs identified as influencing expansion volume were expressed in different environments, suggesting a complex relationship between genetics, environment, and agronomic inputs for popcorn. Moreover, it is possible that new end-use quality factors beyond expansion volume will emerge as desirable traits for popcorn that will place new demands on breeders (Ziegler, 2001). Plant breeding efforts to fulfill new demands might be achieved through better understanding the intermediate factors and pathways for achieving end performance and making more precise selections (Allard and Bradshaw, 1964).

\subsection{Microwave popping performance}

Across all hybrids and environments, unpopped kernels averaged $11.4 \%$ and showed a high coefficient of variation $(46.5 \%)$, which is consistent with the $10-12 \%$ unpopped kernels that consumers typically find in home microwave popping (Quinn et al., 2005) and the high variability reported in previous studies for unpopped kernels after microwave popping (Dofing et al., 1990; Ertas et al., 2009; Gökmen, 2004; Mohamed et al., 1993; Soylu and Tekkanat, 2007).

It has been previously proposed that popping temperature is the most critical factor determining the viability of popcorn kernels to pop (Hoseney et al., 1983). Most unpopped kernels were observed to successfully pop when collected and heated a sec- ond time in microwave tests (Table 4), performing with a comparable average percentage of unpopped kernels (11.5 $\pm 2.6 \%)$ as the original testing (11.4 $\pm 5 \cdot 3 \%)$. This suggests that most unpopped kernels are not inherently unviable, but rather that not all kernels achieve the minimum thermodynamic requirements for popping during microwave heating. In fact, the power absorbance and threshold internal pressure and temperature required for popping is known to vary for individual kernels (Byrd and Perona, 1995). Thus, it may be that unpopped kernels are those kernels in the bag that are shielded from microwaves by other kernels or are positioned along the sides of the bag and do not absorb sufficient reflective energy from the susceptor to achieve critical temperatures required for popping. This may explain why none of the kernel physiochemical parameters correlated with unpopped kernels (Table 5).

Any consumer that has ever reached inside a microwave popcorn bag can attest to the dissatisfaction of messy oil transfer when the hand brushes against the inside of the bag. An average of $15.8 \pm 2.3 \%$ by weight of oil remains with the bag after popping (Table 4). As illustrated in Fig. 1, the amount of oil adhering to the bag has a linear relationship with the original oil amount within the constraints used in this study. Oil loss to the bag represents a considerable opportunity cost for commercial producers. It is probable that using alternative packaging materials or coatings on the bag and/or using different types of oil would affect the oil lost to the bag during microwave popping and would be worth investigating.

Popping performance results also showed significant differences between samples for expansion volume when using both of the methods of determining expansion volume (Table 4). Expansion volumes averaged $44.7 \pm 3.7 \mathrm{~cm}^{3} / \mathrm{g}$ across all runs when using the prevalent method of calculating expansion volume as a function of only the original kernel weight. Despite the prevalence of this method of determination, it neither accounts for the variation in popped flake density as a result of other ingredient additions nor accounts for loss factors during popping. As discussed above, the percentage of unpopped kernels that do not pop can be significant and highly variable. In addition, the density of popped popcorn flakes will vary depending on the amount of oil coverage. This is an important consideration since most prepackaged microwave popcorn sold in the US is coated with a variety of ingredients such as oil, butter, and salt to improve the sensory quality of finished product, and variations in particle density have been suggested to explain the majority of variation in bulk density measurements of other cereal grains (Doehlert and McMullen, 20o8). Thus, while determining expansion volume based on original kernel weight may be reasonable for breeders or producers that sell kernels to commercial venues like movie theaters and athletic venues where popped popcorn is ultimately sold by volume (Hoseney et al., 1983), it may be less germane to producers of packaged goods for retail markets where popcorn must be labeled and sold by weight.

Table 4. Pop performance measures for three popcorn hybrid grown in three different environments. ${ }^{\text {a }}$

\begin{tabular}{|c|c|c|c|c|c|c|}
\hline \multirow[t]{2}{*}{ Factor } & \multirow[t]{2}{*}{ Level } & \multicolumn{2}{|l|}{ Expansion volume } & \multirow[b]{2}{*}{$\begin{array}{l}\text { Unpopped } \\
\text { kernels (\%) }\end{array}$} & \multirow[b]{2}{*}{$\begin{array}{l}\text { Oil lost } \\
\text { to bag (\%) }\end{array}$} & \multirow[b]{2}{*}{$\begin{array}{l}\text { \%Unpopped kernels } \\
\text { after re-popping }\end{array}$} \\
\hline & & $\begin{array}{l}\text { Pop volume }\left(\mathrm{cm}^{3}\right) \text { per } \\
\text { popped flake weight }(\mathrm{g})\end{array}$ & $\begin{array}{l}\text { Pop volume }\left(\mathrm{cm}^{3}\right) \text { per } \\
\text { original kernel weight }(\mathrm{g})\end{array}$ & & & \\
\hline \multirow[t]{2}{*}{ Hybrid } & YPK-213 & $49.4 \pm 6.5 \mathrm{a}$ & $46.5 \pm 4.6 \mathrm{a}$ & $12.5 \pm 6.2 \mathrm{a}$ & $16.5 \pm 3.2 \mathrm{a}$ & $9.6 \pm 2.3 b$ \\
\hline & YPK-321 & $45.9 \pm 7.2 \mathrm{a}$ & $43.8 \pm 3.4 \mathrm{~b}$ & $10.1 \pm 5.3 a$ & $15.0 \pm 2.1 \mathrm{a}$ & $10.7 \pm 2.0 \mathrm{ab}$ \\
\hline \multirow[t]{3}{*}{ Environment } & Indiana & $51.8 \pm 7.8 \mathrm{a}$ & $47.6 \pm 5.3 a$ & $13.2 \pm 4.7 \mathrm{a}$ & $17.5 \pm 2.6 \mathrm{a}$ & $9.3 \pm 1.5 \mathrm{~b}$ \\
\hline & Nebraska & $45.6 \pm 7.1 \mathrm{~b}$ & $43.5 \pm 3.9 b$ & $10.9 \pm 6.2 \mathrm{a}$ & $15.1 \pm 2.1 \mathrm{~b}$ & $11.1 \pm 3.6 \mathrm{ab}$ \\
\hline & Ohio & $44.5 \pm 6.5 b$ & $43.2 \pm 3.4 \mathrm{~b}$ & $10.1 \pm 5.6 \mathrm{a}$ & $14.7 \pm 3.5 b$ & $14.0 \pm 2.6 \mathrm{a}$ \\
\hline
\end{tabular}

a. Mean values \pm SD followed by the same letter within the same column for each design factor (hybrid or environment) are not significantly different $(P<0.05) . n=3$.

b. Unpopped kernels from initial testing were collected, then $28 \mathrm{~g}$ samples were re-popped using a $1250 \mathrm{~W}$ microwave oven. $n=3$. 
Table 5. Correlations ${ }^{\mathrm{a}}$ between popcorn kernel physiochemical parameters and unpopped kernels and expansion volume. ${ }^{b}$

\begin{tabular}{|c|c|c|c|}
\hline & \multicolumn{3}{|c|}{ Expansion volume } \\
\hline & $\begin{array}{l}\text { Unpopped } \\
\text { kernels }\end{array}$ & $\begin{array}{l}\text { Pop volume } \\
\left(\mathrm{cm}^{3}\right) \text { per } \\
\text { popped flake } \\
\text { weight }(\mathrm{g})\end{array}$ & $\begin{array}{l}\text { Pop volume } \\
\left(\mathrm{cm}^{3}\right) \text { per } \\
\text { original kernel } \\
\text { weight }(\mathrm{g})\end{array}$ \\
\hline \multicolumn{4}{|l|}{ Physical parameters } \\
\hline Thousand-Weight & -0.565 & $-0.729^{*}$ & $-0.708^{*}$ \\
\hline Test Weight & 0.226 & 0.107 & 0.077 \\
\hline Pycnometer Density & -0.348 & -0.187 & -0.187 \\
\hline Stenvert Time-to-Grind & 0.297 & 0.310 & 0.217 \\
\hline Stenvert Height & -0.242 & -0.381 & -0.314 \\
\hline TADD index & -0.138 & -0.224 & -0.167 \\
\hline Sphericity & 0.469 & $0.788^{*}$ & $0.835^{*}$ \\
\hline \multicolumn{4}{|l|}{ Composition factor } \\
\hline Total Fat & -0.573 & $-0.797^{*}$ & $-0.824^{* *}$ \\
\hline Total Carbohydrate & -0.273 & -0.348 & -0.253 \\
\hline Starch & -0.168 & -0.427 & -0.525 \\
\hline Amylose & -0.519 & -0.131 & -0.007 \\
\hline Amylopectin & -0.006 & -0.415 & -0.562 \\
\hline Dietary Fiber & -0.209 & 0.080 & 0.269 \\
\hline Sugars & -0.584 & -0.619 & -0.477 \\
\hline Protein & 0.381 & 0.440 & 0.337 \\
\hline Total Minerals & -0.491 & -0.040 & 0.118 \\
\hline Palmitic Acid & -0.115 & -0.053 & -0.105 \\
\hline Stearic Acid & -0.156 & -0.381 & -0.521 \\
\hline Oleic Acid & -0.479 & $-0.890^{* *}$ & $-0.966^{* *}$ \\
\hline Linoleic Acid & -0.645 & $-0.801^{* *}$ & $-0.791^{*}$ \\
\hline Linolenic Acid & 0.083 & 0.182 & 0.087 \\
\hline
\end{tabular}

a. Correlation coefficients greater than $|r|=0.45$ are bold-printed. * Significance at $p<0.05 ;{ }^{* *}$ significance at $P<0.01$.

b. Analysis used compositional data on the basis of $14.0 \%$ moisture content (wb) in kernels. $n=9$.

The method proposed by Pordesimo et al. (1990) divides pop volume by the weight of popped flakes only, thereby eliminating the influence of unpopped kernels and the weight of oil lost to the bag during popping in calculations. Using this method of determination resulted in expansion values of $47.3 \pm 6.4 \mathrm{~cm}^{3} / \mathrm{g}$ across all runs in this study. In effect, this method of reporting expansion volume effectively expresses the inverse of bulk density. The primary advantages of this method are that it is not biased by loss factors due to oil retained by the bag or unpopped kernels, and it accounts for the contribution of other ingredients to the bulk mass. Ultimately, it is important to recognize that expansion volume is a complex trait that is also a function of packing efficiency and the measurement of pop volume itself, which is influenced by factors such as the size and shape of individual flakes and void spaces between flakes.

Thousand-kernel weight, sphericity, total fat, oleic acid, linoleic acid exhibited significant correlations with both expressions of expansion volume (Table 5 ). The negative correlation between thousand-kernel weight and expansion volume agrees with previous findings (Ceylan and Karababa, 2001). In addition, the negative correlation between levels of oleic acid and pop expansion volume agrees with previous results reported by Borras et al. (2006) for seven Argentinean popcorn hybrids. However, the findings in this study disagree and are opposite to the findings by Borras et al. of a significant positive correlation between expansion volume and levels of linoleic acid. This divergence may be a result of the different hybrids or popping methods (conventional oil popping versus microwave popping) used in the two studies, or because this study determined correlations to fatty acids as a percentage of the total kernel composition instead of fatty acids as a percentage of total lipids.

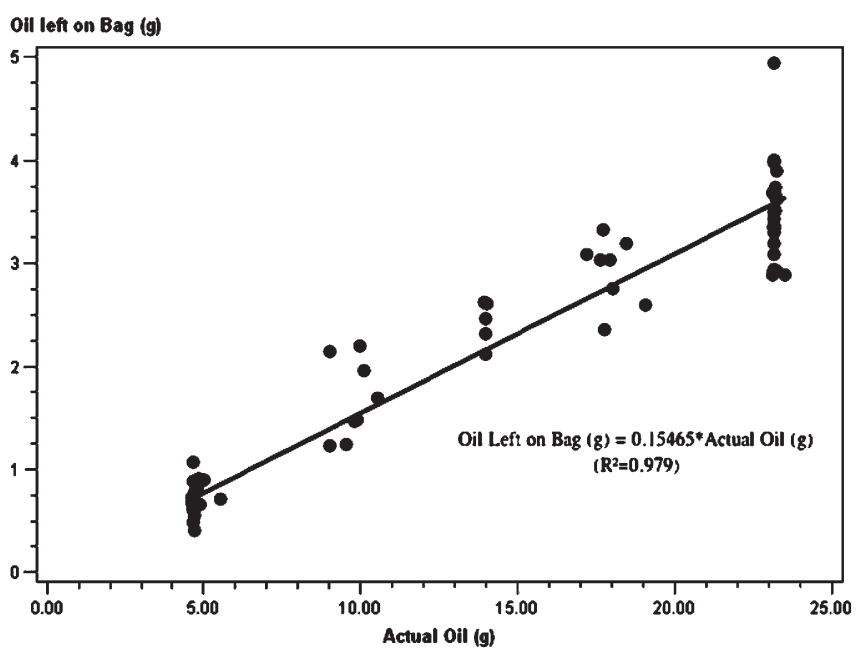

Fig. 1. Oil amount lost to bag during microwave popping.

Kernel sphericity was positively correlated with expansion volume, which agrees with the findings from several previous studies (Ertas et al., 2009; Mohamed et al., 1993; Pordesimo et al., 1990). The importance of structural geometry of popcorn kernels can be explained by considering that dynamic fragmentation of granular materials can be predicted from the stored elastic and kinetic energy (Griffith, 1921). Probability modeling from fracture mechanics predicts the failure mode for pressurized vessels to occur at the weakest point in the structure (Bargmann, 1986) and reveals that critical pressures for fragmentation to be a function of surface area to volume ratio of the particles (Pungno and Carpinteri, 2008). Moreover, previous work on popcorn kernels has shown that increasing the difference between internal kernel pressure and the external atmospheric pressure increases expansion volume (Quinn et al., 2005). Thus it may be that more spherical popcorn kernels have greater structural stability due to a smaller surface area to volume ratio and are thus able to build greater energy potential before popping occurs.

Expansion volume is the only quality trait of popcorn that can be readily measured, and evaluation of popcorn hybrids at early stages of testing is often limited by small sample sizes which makes measuring pop volume precarious (Ziegler, 2001). While this study was limited to three hybrids and growing locations in the USA, understanding kernel physiochemical parameters that correlate with expansion volume may help lead to the development and use of simple and non-destructive methods that can be leveraged universally by popcorn breeders and producers for predicting expansion volume. For example, total fat might be non-destructively estimated using near infrared spectroscopy, and an automatic seed counter might be used to rapidly segregate kernels for thousand-weight measurement. In addition, the positive correlation between kernel sphericity and expansion volume established previously and corroborated in this study suggests that developing a simple and rapid method of determining kernel sphericity would be beneficial.

\section{Conclusions}

Significant differences were observed in the physical and biochemical characteristics of popcorn kernels used in this study. Significant positive correlations were observed between Stenvert time-to-grind and protein, and a positive correlation between time-to-grind and total carbohydrates and test weight. Protein was negatively correlated with both sugars and total carbohydrates. Starch and fiber were also negatively correlated. 
Hybrid and environment effects on popcorn kernel physiochemical parameters are varied. Among some key characteristics, the main effect of hybrid alone affected sphericity, time-togrind, dietary fiber, sugars, and starch. Environment main effect was observed to influence total minerals. The main effects of both hybrid and environment affected test weight, TADD Index, thousand-weight, protein, and total carbohydrates.

Determining microwave popcorn expansion volume as a function of pop volume per popped flake weight may be a more appropriate method than on the basis of original kernel weight, since it accounts for unpopped kernel loss factors and the contribution of ingredient additions to the kernel which contributes to the bulk density. For both methods of determination, expansion volume is positively correlated with kernel sphericity and negatively correlated with thousand-kernel weight, total fat, and levels of oleic and linoleic acid. The amount of oil retained by paper bags during microwave popping is noteworthy and increases as a function of starting oil amount.

Acknowledgments - In-kind support was provided by ConAgra Foods to support this research. Author J. C. Sweley is an employee of ConAgra Foods.

\section{References}

AOAC, 2010. Official Methods of Analysis, 18th ed. Association of Official Analytical Chemists, Washington, DC.

Allard, R. W., Bradshaw, A. D., 1964. Implications of genotype-environmental interactions in applied plant breeding. Crop Science 4, 503-508.

Bargmann, H. W., 1986. Prediction of pressure vessel failure: A critical review of the probabilistic approach. Theoretical and Applied Fracture Mechanics 5, 1-16.

Borras, F., Seetharaman, K., Yao, N., Robutti, J. L., Percibaldi, N. M., Eyherabide, G. H., 2006. Relationship between popcorn composition and expansion volume and discrimination of corn types by using zein properties. Cereal Chemistry 83, 86-92.

Byrd, J. E., Perona, M. J., 1995. Kinetics of popping of popcorn. Cereal Chemistry 82, 53-59.

Ceylan, M., Karababa, E., 20o1. Comparison of sensory properties of popcorn from various types and sizes of kernel. Journal of the Science of Food and Agriculture 82, 127-133.

Doehlert, D. C., McMullen, M. S., 2008. Oat grain density measurement by sand displacement and analysis of physical components of test weight. Cereal Chemistry 85, 654-659.

Dofing, S. M., D'Croz-Mason, N., Buck, J. S., 1991. Inheritance of expansion volume and yield in two popcorn $\times$ dent corn crosses. Crop Science $31,715-718$.

Dofing, S. M., Thomas-Compton, M. A., Buck, J. S., 199o. Genotype × popping method interaction for expansion volume in popcorn. Crop Science 30, 62-65.

Dorsey-Redding, C., Hurburgh, C. R., Johnson, L. A., Fox, S. R., 1990. Adjustment of maize quality data for moisture content. Cereal Chemistry 67, 292-295.

Dorsey-Redding, C., Hurburgh, C. R., Johnson, L. A., Fox, S. R., 1991. Relationship among maize quality factors. Cereal Chemistry 68, $602-605$.

Ertas, N., Soylu, S., Bilgicli, N., 2009. Effects of kernel properties and popping methods on popcorn quality of different corn cultivars. Journal of Food Process Engineering 32, 478-.

Greaves, J. E., Hirst, C. T., 1929. The mineral content of grain. Journal of Nutrition 1, 293-298.

Griffith, A. A., 1921. The phenomena of rupture and flow in solids. Philosophical Transaction of the Royal Society, Series A 221, 163-198.

Gökmen, S., 2004. Effects of moisture content and popping method on popping characteristics of popcorn. Journal of Food Engineering 65, $357-362$.
Hoseney, R. C., Zeleznak, K., Abdelrahman, A., 1983. Mechanism of popcorn popping. Journal of Cereal Science 1, 43-52.

Lee, K. M., Herrman, T. J., Rooney, L., Jackson, D. S., Lingenfelser, J., Rausch, K. D., McKinney, J., Iiams, C., Byrum, L., Hurburgh, C. R., Johnson, L. A., Fox, S. R., 2007. Corroborative study on maize quality, dry-milling and wet-milling properties of selected maize hybrids. Journal of Agricultural and Food Chemistry 55, 10751-10763.

Li, Y., Dong, Y., Niu, S., 2006. QTL analysis of popping fold and the consistency of QTLs under two environments in popcorn. Acta Genetica Sinica 33, 724-732.

Lu, H.J., Bernardo, R., Ohm, H. W., 2003. Mapping QTL for popping expansion in popcorn with simple sequence repeat markers. Theoretical and Applied Genetics 106, 423-427.

Mohamed, A. A., Ashman, R. B., Kirleis, A. W., 1993. Pericarp thickness and other kernel physical characteristics relate to microwave popping quality of popcorn. Journal of Food Science 58, 342-346.

National Agricultural Statistics Service, 2007. Census of Agriculture. USDA, Washington, DC. Retrieved April 7, 2010 from: http://www. agcensus.usda.gov/Publications/2007/Full Report/Volume 1, Chapter 2 US State_Level/st99 2 026 026.pdf

Park, D., Allen, K.G.D., Stermitz, F. R., Maga, J. A., 20oo. Chemical composition and physical characteristics of unpopped popcorn hybrids. Journal of Food Composition and Analysis 13, 921 e934.

Pomeranz, Y., Czuchajowska, Z., Martin, C. R., Lai, F. S., 1985. Determination of corn hardness by the Stenvert hardness tester. Cereal Chemistry 62, 108-112.

Pomeranz, Y., Martin, C. R., Traylor, D. D., Lai, F. S., 1984. Corn hardness determination. Cereal Chemistry 61, 147-150.

Pordesimo, L. O., Anantheswaran, R. C., Fleishmann, A. M., Lin, Y. E., Hanna, M. A., 1990. Physical properties as indicators of popping characteristics of microwave popcorn. Journal of Food Science 55, 1352-1355.

Pungno, N. M., Carpinteri, A., 2008. On linear elastic fragmentation mechanics under hydrostatic compression. International Journal of Fracture 149, 113-117.

Quinn Sr., P. V., Hong, D. C., Both, J. A., 2005. Increasing the size of a piece of popcorn. Physica A 353, 637-648.

Reichert, R. D., Tyler, R. T., York, A. E., Schwab, D. J., Tatarynovich, J. E., Mwasaru, M. A., 1986. Description of a production model of the tangential abrasive dehulling device and its application to breeder's samples. Cereal Chemistry 63, 201-207.

Schiffmann, R. F., 1987. Performance testing of products in microwave ovens. Microwave World 8, 7-9, 14.

Shandera, D. L., Jackson, D. S., Johnson, B. E., 1997. Quality factors impacting processing of maize dent hybrids. Maydica 42, 281-289.

Soylu, S., Tekkanat, A., 2007. Interactions amongst kernel properties and expansion volume in various popcorn genotypes. Journal of Food Engineering 80, 336-341.

Sweley, J. C., Rose, D. J., Jackson, D. S., 2011. Composition and sensory evaluation of popcorn flake polymorphisms for a select butterfly-type hybrid. Cereal Chemistry 88, 321-327.

Stuber, C. W., Lincoln, S. E., Wolff, D. W., Helentjaris, T., Lander, E. S., 1992. Identification of genetic factors contributing to heterosis in a hybrid from two elite maize inbred lines using molecular markers. Genetics 132, 823-839.

Tandjung, A. S., Janaswamy, S., Chandrasekaran, R., Abaoubacar, A., Hamaker, B. R., 2005. Role of the pericarp cellulose matrix as a moisture barrier in microwaveable popcorn. Biomacromolecules 6, 1654-166o.

U.S. Department of Agriculture, Agriculture Research Service, 2010. USDA National Nutrient Database for Standard Reference, Release 23; retrieved May 15, 2011 from: http://www.ars.usda.gov/ba/bhnrc/ ndl

USDA, 1990. General information. In: Grain Grading Procedures. USDA Federal Grain Inspection Service, Washington, DC, pp. 15-17.

Zhu, T., Jackson, D. S., Wehling, R. L., Geera, B., 2008. Comparison of amylose determination methods and the development of a dual wavelength iodine binding technique. Cereal Chemistry 85, 51-58.

Ziegler, K. E., 2001. Popcorn. In: Hallauer, A. (ed.), Specialty Corn. CRC Press, Boca Raton, FL, pp. 199-234. 